\title{
Research on the Talent Reserve and Training Mode of Sichuan College Game Art
}

\author{
Gao Zhongli \\ Academy of Fine Arts in Chengdu, Sichuan Conservatory of Music, Chengdu 610500, China \\ gaozhongli@126.com
}

Keywords: game art, talent reserve, training mode

\begin{abstract}
Nowadays, the competition of comprehensive national strength has shifted from a single economic complex to an innovative economic competition based on cultural soft power as the main form of output. It is the era of creative economy soaring, and vigorously developing cultural and creative industries is the general trend. China's game industry has now become a very important part of the creative culture industry in China. With the rapid development of the times, the development and design of games in China has higher standards than before. This is a new proposition for colleges and universities that cultivate talents. Chengdu is the new first line of China's National Center City, and it is the major town of China's game research and development and production. In Sichuan, the training of game art talents in colleges and universities is based on the demands of the game R \&amp; $\mathrm{D}$ and production enterprises in Chengdu. By analyzing the problems in the process, it is learned that it is necessary to focus on the "reserve and training mode of game art talents in Sichuan universities", hoping to propose some suggestions for this in the new era.
\end{abstract}

\section{The overall situation of the game industry in China}

"2017 China game industry report" summed up the overall market revenue in 2017 was 203 billion 610 million China game industry; China game users has reached 583 million people; by the end of 2017, the number of Chinese listed gaming enterprises reached 185, of which A shares listed gaming company 151, accounting for $81.6 \%$; the Hong Kong stock market game company 26, accounting for $14.1 \%$ of the United States; the game shares listed 8 companies, accounting for $4.3 \%$; approved by the State Administration of press and publication published about 9800 game models, the domestic game about 9310, about 490 of imported games, the domestic game accounted for absolute proportion in Chinese game industry output value; overseas market, Chinese self-developed online games overseas market actual sales revenue reached 8 billion 280 million dollars, an increase of $14.5 \%$; as an important cultural and creative products, China self-developed game is going to have on the world more and more The influence.

\section{The scale and situation of the game enterprises in Sichuan}

The game companies in Sichuan are mainly concentrated in Chengdu. According to statistics, at present, there are about 390 games related businesses in Chengdu, but the gaming industry in Chengdu has experienced explosive growth, and the game team has reached more than 1000. From the beginning of 2015, the Chengdu gaming industry began to shuffle, entering a more rational and mature stage of development, mainly reflected in two aspects: on the one hand the resources to focus on a small number of high-quality enterprises further; on the other hand, the National Games of the "king of glory" in the birth of Chengdu, also hit a booster for the Chengdu gaming industry". Now the industry concentration is still at a high level, and 16 enterprises with revenues of over 100 million contribute nearly $85 \%$ of business revenue in Chengdu game area. Under the rule of survival of the fittest, many teams that cannot find investment and lack core competitiveness can only face the outcome of elimination. 


\section{The importance of game art design and the present situation of talent}

Game industry chain is composed of four aspects: game R \&amp; D, game distribution, distribution channel and operation support. Game art is an essential and very important part of the game research and development. Art design excellence is needed to keep a good games, games can enhance the brand image, enhance the aesthetic interest and the game player, the game will make the products with the development of the recognition, can enhance the competitiveness of the market operation and promotion, but also facilitate the game peripherals products strong.

The rapid development of the game industry has prompted the quality of game products to continue to improve and improve. The requirements of the game art become more severe. At present, the whole game industry is short of the demand for "high talent". Most of the talents trained in Colleges and universities have a certain or greater distance from the requirements of the post, so it is often vicious competition in the industry to "dig for talents".

\section{A survey of the reserve of game art talents in Colleges and universities in Sichuan}

There are 109 colleges and universities in Sichuan (including higher vocational and technical colleges), according to incomplete statistics, of which nearly 40 colleges and universities have art and design majors. Nearly 40 colleges and universities of art and design in Sichuan, about 20 colleges and universities set up animation professional, new media art or CG related courses, and there are not many schools that have game design major. According to incomplete statistics, the number of all the above major in the school is about 5000, and the number of graduates is more than 1000 per year. Some of the graduates focus on animation, some focus on new media art technology applications, some focus on CG illustration and picture books. Few of them will focus on Game Art Design of "full process teaching". The reasons will be discussed later.

\section{Research on the training mode of Sichuan College Game Art Talents}

\subsection{Existing problems}

\subsubsection{Low entrance threshold and thin fine arts}

In 2017, the number of people who passed the art college entrance examination in Sichuan province was 27945 , of which nearly $70 \%$ of them were not satisfied with their cultural achievements. They took the shortcut approach, and after several months' cram style art examination intensified training, they hurried onto the "Mei Ke" road. Professional passing is not very difficult. In addition, with the "parallel volunteer" way to volunteer, especially in private universities, the competition for students is fierce, so the threshold of last university is not high. But most of the students are thin in fine arts.

\subsubsection{Colleges and universities are blindly running school and the teachers are thin}

With the development of the times and the needs of the industry, some colleges and universities do not have the game art design major or curriculum under the premise of increasing the enrollment gimmick to enhance the competitiveness of the students, but also open the specialty blindly for improving economic efficiency. In order to quickly set up a professional, usually from other related professional personnel engaged in teaching and post haste to the teachers, because of the lack of understanding of the industry, but the lack of project experience and practical experience, therefore in the teaching of students in the industry tend to ignore the aesthetic aspect and creative thinking, also deviated from the industry specification. 


\subsubsection{The target of talent training is vague and the curriculum is old}

The types of colleges and universities are different, and the target of talent training should be different. However, because of the blind creation of professional lack of understanding and analysis of industry trends and demand, and is also a lack of effective communication and exchange of enterprises, more important is not correct assessment of whether to have the school running conditions, so even to recruit students into the school, but the school develop to the personnel training goal is hasty and fuzzy. The course is often to the college or universities will blindly draw teaching materials put all sorts of things together. Teaching plans and curricula are often taken as a matter of course and lack of scientificity and systematicness.

\subsubsection{School enterprise cooperation is more divorced from reality}

The cooperation between school and enterprise is a good thing. It is an important link to train the integration of "production, learning and research", but the real successful cases are few. Many colleges and universities are not allowed to go out for internships in school for safety considerations, but to the introduction of enterprises to schools. However, the school especially public university enterprise cooperation or management approval process cumbersome, everything needs to demonstrate and for a long time, for this in pursuit of "efficiency" and "benefit" as the ultimate purpose of the enterprise is a kind of constraints, so many companies for "in Colleges and universities in this form to flinch. Another way is part of the college until the graduate students, students will be sent to the whole enterprise training, called cooperation. Because the enterprise training cost is higher, so tend to become "paid training" to the end, students complained that the school run, eventually vanish like soap bubbles.

\subsection{Research on the training mode of game art talents}

\subsubsection{Science should work out the goal of talent cultivation in the field}

The training of talents must be "targeted". To set up the major of game art design, we must understand the development trends and trends of the industry, the standards and requirements of the industry. The game art design includes "the original character design, scene design, the original 3D 3D 3D role, scene, action, special effects, UI design, animation, beauty propaganda" and other posts, each post in the instruction corresponding to at least a course. Before that, students must have the basic ability of three parts: modeling ability (sketch, sketch), color application, software application (PS, PAINT, 3DMAX, MAYA, PRO, AE, ZBRUSH). Different training objectives should be ordinary colleges and higher vocational college talent, the former may focus on the comprehensive design of talent cultivation, which focused on the technical application personnel training; in fact need not all courses offered, their corresponding precision industry demand, high school to find their own position do a professional characteristic.

\subsubsection{Distributary teaching, early entering the major}

Many college students are recruited into the first general theory basis of a few years, and last year into professional graduation design, some institutions do not even have the specialization. For a few years, students often learn "not to find the north", and the knowledge is unsystematic and unsystematic. Colleges should clearly set the professional direction, for example, is divided into two-dimensional and three-dimensional, digital painting, post effects and other small direction, or a type for the game set of small professional direction, students will contact as soon as possible as soon as possible diversion of teaching, and enter the professional, clear and development direction in the future employment space, do "specialize in".

\subsubsection{Increase the proportion of "Elective Courses" and prepare for "Pan employment"}

In addition to basic courses and professional courses, it is suggested to increase the proportion of elective courses. The commercial value can not be created around the product development of a game, 
so the game by the extension of the "open hand model, toy development, costume design, COSPLAY, CG picture books, movies, cartoons and illustrations..." It will correspond to the related courses such as "sculpture, product design, CG painting, film and television language, animation design" and so on. Now the game art talents on the general demand of the industry is already saturated, then we can from the perspective of "Pan employment" to increase the cultivation of applied talents around the corresponding product development, expand employment, even because of intense competition can not accurately position, at least in specialized areas "to lay the foundation for universal employment". To facilitate students to.

\subsubsection{Effectively use the network platform to strengthen the construction of "electronic textbook"}

In today's era has been in the "era of big data information Internet plus", the face of the rapid development of science and technology, we should follow the development of the times, vigorously strengthen the construction of the "electronic textbooks". A method of artistic creation in a variety of ways, teachers can build a APP platform according to the professional characteristics and their own personal experience, to facilitate real-time teaching, is also helpful to guide students to learn more easily through the Internet will spread the excellent teaching and self-study resource sharing, reflect the greater value of textbooks ".

\subsubsection{Encourage teachers to learn from enterprises}

Carry out the system or method of encouraging teachers to go to college for further study, and regard it as a hard condition or a plus premise, which is included in the evaluation of teachers' professional titles, and at the same time, they are rewarded and subsidized. University Teachers' long-term stay in the campus, and the concept of experience is often not a courseware of market competition, some teachers can change 10 years, knowledge has not taught backward may have been eliminated, this is undoubtedly fatal for the application of art design discipline. Therefore, encouraging teachers to go to business training is not only conducive to improving teachers' professional level, but also, closely related to the needs and norms of the industry, and designing and teaching with the times, so that students can learn to apply their knowledge.

\subsubsection{Teacher studio system drive project actual work}

The teacher's studio can be used as a window and platform for the cooperation between school and enterprise. The studios set up by the students are more tender and lack the advantages of planning and social resources. "Students to manage their own" lack of binding and authoritative; now many students work also needs to be considered integrity and tenacity. University Teachers in class may spare more time, schools can encourage prior to the "enterprise after learning to teacher" teachers in the school set up the studio, the school to give preferential policies and subsidies for certain. For teachers, received a business project, from the students according to their willingness to select talent project team to work, teachers should set up their own team, but also from the project commission to create economic value, at the same time, the project can also be used as a personal work performance reporting promotion; for students in the school can not only advance internship training project experience, can also work, create a certain economic value; for the school, not only can solve the problem of students in the school, but also facilitate the safety management, and establish a certain scale of the talent pool; for enterprises, teachers will provide the management and guidance of students, therefore the project personnel the cost will be reduced, at the same time can build up talent team for their own. If a teacher's studio operates properly, it will be a good thing for the four parties to benefit.

\subsubsection{Strengthen the interaction and connection between school and enterprise}

Many colleges and universities only take the initiative to contact enterprises to understand their job demands and employment situations when they are graduating. Outstanding talents need to be cultivated by a systematic project. Education is not only a responsibility of schools, but also a 
responsibility for employing enterprises. Therefore, normal interaction and connection between schools and enterprises should be normalized. Both sides can make a two-way choice after the correct assessment and sign a "talent training order". Enterprises can set up a scholarship, the school opened the industry academic seminars, organized professional competitions, sent to the school for teaching unit of backbone enterprises, funding and support personnel training plan in a variety of ways to build up the talent pool and talent selection; the school can organize students to visit the enterprise, understand the project implementation process, the industry needs and development trends, let the students as soon as possible to contact the industry, a clear goal.

\section{Conclusions}

It is the trend of the times to develop cultural and creative industries in the era of creative economy. Game industry is very important in the development of innovation industry in the new period of China. The current level of game research and development and market share in China are in the forefront of the world, and the game industry in Sichuan is also very important in China. The game art has changed from "the demand of general talent" to "high talent demand", while the demand for "Pan art talents" is relatively large. Although in different levels and types are different, but it should be based on the development of times, target, adjustment and improvement of the traditional teaching mode to cultivate clear orientation and talent, according to social needs, strengthen cooperation in order to better cultivate all kinds of practical people of different levels only.

\section{Acknowledgements}

Project source: research project of Sichuan animation research center "Research on the reserve and training model of Sichuan college game art talents".

Item number: DM201506.

\section{References}

[1] "Report on the development of Chengdu Internet Network in 2016".

[2] China Game Industry Report 2017. 